ROCZNIKI HUMANISTYCZNE

Tom LXVII, zeszyt $10-2019$

DOI: http://dx.doi.org/10.18290/rh.2019.67.10-8

KLAUDIA MUCHA-IWANICZKO

\title{
WSPÓŁCZESNE KSIĄŻKI O SZTUCE JAKO NARZĘDZIE DYDAKTYCZNE NA ZAJĘCIACH JĘZYKA POLSKIEGO JAKO OBCEGO
}

Sztuka tworzy przestrzeń do rozmowy na temat emocji, wymiany doświadczeń, obserwacji świata. Tej rozmowie towarzyszą barwy, faktury, uchwycone przez artystę momenty życia, poważne postacie czy też zabawne karykatury. Ze względu na de facto nieskończoną tematykę, jaką może podejmować dzieło sztuki, wykorzystanie go podczas zajęć z języka obcego to nie tylko ciekawe urozmaicenie lekcji. Obraz czy rzeźba z powodzeniem mogą stanowić główną oś lekcji, wokół której kształcone są wszystkie sprawności językowe wraz z kompetencją kulturową. Prezentowane w niniejszym artykule rozwiązania dydaktyczne skierowane są do nauczycieli pracujących z grupami dzieci i młodzieży, które uczą się języka polskiego jako obcego zarówno w polskim systemie edukacji, jak i na kursach językowych. Poziom uczniów celowo nie został określony, ponieważ prezentowane materiały mogą zostać dostosowane przez nauczyciela do umiejętności językowych i potrzeb grupy. W związku z tym, że powstało wiele dobrych opracowań i artykułów na temat pracy z dziełem sztuki podczas zajęć językowych, postanowiłam, nie powielając dotychczasowych publikacji, zaproponować rozwiązania dydaktyczne, które wykorzystują współczesne książki o sztuce dla dzieci. Celem artykułu jest zwrócenie uwagi czytelników na wykorzystywanie potencjału wspomnianych dzieł na zajęciach języka polskiego jako obcego i zainspirowanie do tworzenia kolejnych materiałów dydaktycznych na podstawie omówionych pozycji.

Praca z tekstem kultury, jakim jest dzieło sztuki, wiąże się z „aktywnym obserwowaniem", czyli niejako czynnym aktem rozmowy twórczej z własnym

\footnotetext{
Mgr Klaudia Mucha-IwaniczKo - doktorantka literaturoznawstwa na Wydziale Polonistyki UJ, nauczycielka języka polskiego oraz glottodydaktyk. W swojej pracy badawczej zajmuje się tożsamością kulturową młodzieży z doświadczeniem migracji; e-mail: klaudiamucha71@gmail.com
} 
doświadczeniem i osobistą wrażliwością. Dzięki tej możliwości sztuka jest świetnym narzędziem podczas kształcenia kompetencji komunikacyjnej. Choć to niewątpliwie jedna $\mathrm{z}$ wielu możliwości pracy z zaproponowanymi tekstami. Dzieło jest przede wszystkim nośnikiem treści kulturowych, więc wykorzystywanie go na lekcjach wpisuje się we współczesne tendencje w nauczaniu języków obcych, gdzie podkreśla się rolę uczenia kompetencji kulturowej wraz z innymi sprawnościami (czytanie, pisanie, mówienie, słuchanie). Pracę z obrazem podczas lekcji można opisać jako metodę przekładu intersemiotycznego, czyli tzw. transmutację, gdzie znaki językowe są interpretowane za pomocą znaków niejęzykowych ${ }^{1}$. Ewa Lipińska w artykule Przekład intersemiotyczny $w$ glottodydaktyce polonistycznej wskazuje, za Teresą Tomaszkiewicz, zalety pracy tą metodą:

[...] komunikaty wyrażone znakami językowymi mają charakter liniowy i rozwijają się w czasie, gdy tymczasem obrazy mają charakter przestrzenny, pozbawiony wymiaru czasowego. Oznacza to, że są bardzo pomocne dla uczących się o preferencji prawopółkulowej. Jest to o tyle ważne, że w dydaktyce dominuje system nauczania faworyzujący lewą półkulę, konieczne jest więc uaktywnienie prawej części mózgu, nieco uśpionej. [...] Współdziałanie obydwu półkul sprawia, że mózg pracuje wydajnie. Synergię tę generuje metoda przekładu intersemiotycznego, polegająca na mediacji między kodem werbalnym a niewerbalnym ${ }^{2}$.

\section{WSPÓŁCZESNE KSIĄŻKI O SZTUCE - CHARAKTERYSTYKA GATUNKU}

Obecnie na rynku wydawniczym jest bardzo wiele pozycji skierowanych do młodszych pasjonatów sztuki. Współczesne książki o sztuce są ciekawą propozycją, która może zaistnieć podczas lekcji, szczególnie ze względu na połączenie dzieła sztuki z omówieniem (tekstem) dostosowanym do możliwości młodych odbiorców. W przypadku nauki języka obcego nie ma potrzeby kierowania się wiekiem sugerowanym przez wydawnictwo, bowiem prezentowane treści z powodzeniem można dostosować do kompetencji językowych uczniów. Współczesny rynek książki oferuje wiele - od klasycznych, ale dostosowanych do młodszego odbiorcy encyklopedii, słowników o sztuce po fabularyzowane książki na temat życia artystów, jak i powieści czy zbiory opowiadań „ze sztuką w tle”. Pojawiają

${ }^{1}$ Za: E. LiPIŃSKA, Przekład intersemiotyczny $w$ glottodydaktyce polonistycznej, w: Ttumaczenie dydaktyczne w nowoczesnym ksztatceniu językowym, pod red. E. Lipińskiej, A. Seretny, Kraków: Księgarnia Akademicka 2016.

${ }^{2}$ Tamże, s. 146. 
się również książki stricte związane z twórczością artystyczną dzieci, które mają inspirować do tworzenia własnych dzieł sztuki. Wiele muzeów wydaje przewodniki związane z tematyką konkretnej wystawy, które są dostosowane do młodszych odwiedzających. Warto wykorzystywać je podczas wizyty w galerii.

Próbując skategoryzować tego typu utwory, należy podkreślić, że łączą one styl naukowy, popularnonaukowy wraz z literacką fikcją, tworząc tym samym dzieła na pograniczu gatunków. Poprzez sposób prezentowania treści mogą być one analizowane w kontekście badań nad ilustracją i porównywane do tzw. picture books:

Picture book jako materiał daje wiele możliwości i otwiera przeróżne ścieżki badawcze. Jest to książka ikonolingwistyczna, w której tekst i obraz odgrywają zwykle równorzędną rolę. Czasem wiodącą funkcję pełni obraz, zaś krótki, parozdaniowy tekst jest właściwie pretekstem do zbudowania sobie na kanwie obrazu opowieści. Tekst nie może być zbyt „pokazujący” [...] tekst w picture book jest bez obrazu w pewnym stopniu nie do odczytania, nie funkcjonuje autonomicznie, ponieważ rozwiązanie opowieści znajdujemy dopiero w obrazie. Podobnie z obrazem - sam jest niepełny. Dopiero związek tych dwóch płaszczyzn, spójność obrazu i tekstu daje nam picture book3.

Znamienitą cechą picture books jest możliwość wielokrotnej lektury. Podobnie można traktować książki o sztuce - odbiorca może na nowo odkrywać obrazy ujęte w dziele i odczytywać teksty. Picture books w nauce określane jest jako „książka obrazkowa”, jednakże badacze wskazują, że nie jest to najbardziej trafne językowo określenie, bowiem nie objaśnia dokładnie terminologii. Bardzo ważną rolę w odkrywaniu treści pełnią dorośli, stając się niejako przewodnikami: „[...] książka obrazkowa jest specyficznym medium kulturowym, które zakłada dość silny wpływ pośredników, a zatem to właśnie od nich (czyli od dorosłych) zależy w dużej mierze jakość udziału dziecka w kulturze, jakość inkulturacji”", co jest dowodem na to, że picture books stawiają nauczycielowi edukacyjne wyzwania, wymagając od niego świadomego i celowego użycia podczas lekcji.

Do tych rozważań warto dodać refleksję Grzegorza Leszczyńskiego i Michała Zająca, którzy rozważają pojęcie picture books w następujący sposób:

przy kreowaniu przekazu wychodzi poza tradycyjny (dla książek obrazkowych czy ogólnie - ilustracji) symetryczny układ komunikacyjny: samoistny tekst (pełniący

\footnotetext{
${ }^{3}$ E. KruszyńsKa, ,, O kryzysie czytania i ksiażce ikono lingwistycznej”. Dziecko i literatura we współczesnym świecie, pod red. B. Moraczewskiej, E. Oberlana, Włocławek: Państwowa Wyższa Szkoła Zawodowa 2012, s. 61.

${ }^{4}$ Tamże, s. 61.
} 
rolę głównego przekaźnika) i obrazek, który zawiera ikoniczną jego wersję i interpretację, dopełnienie. [...] korzenie zjawiska sięgają głębiej: do zmian dostrzegalnych w kulturze współczesnej, w szczególności w dziedzinie mediów. W świecie „uobrazowanym” zdominowanym przez telewizję, ilustrowane czasopisma, nośniki reklamy, Internet status obrazu jako nośnika informacji jest coraz wyższy. Mówi się już niekiedy o Visual literacy czyli o umiejętności właściwego odczytywania kodów narracyjnych przekazywanych za pomocą obrazu 5 .

Analizowane w artykule książkowe propozycje łączą ilustracje wraz z tekstem $^{6}$, który pełni funkcję komentarza do zamieszczonej grafiki. Ewa Piwowarska w pozycji na temat ilustracji wskazuje (za Karolem Głombiowskim), że na przestrzeni wieków wykształciły się 2 sposoby ilustrowania książek - opisowy oraz interpretacyjny ${ }^{7}$. Pierwszy z nich, charakterystyczny dla dzieł naukowych, objaśnia tekst poprzez wyobrażenie wzrokowe albo poprzez informację poglądową, która dołączona jest do tekstu. W tym nurcie ilustracja ma rolę służebną wobec tekstu i ma na celu bezpośrednio pokazywać treść. Drugi typ charakteryzuje się interpretacją treści tekstu: „opatrzenie za pomocą plastycznych środków wyrazu dodatkowym twórczym komentarzem, stanowiącym - z założenia - przejaw artystycznej niezależności ilustracji”». Jak podkreśla autorka - w edukacji szkolnej korzysta się z obu wskazanych sposobów, łącząc funkcję przekazywania treści wynikających z tekstu z aktywizowaniem wyobraźni uczniów i inspirowaniem do własnych przemyśleń, wynikających z kontaktu z dziełem literackim i jego plastyczną interpretacją. Ilustracja jako kod produkowany przez człowieka posiada zasadnicze funkcje: zdobniczą (nadaje walory estetyczne), interpretacyjną (wyjaśnia), ekspresywną (buduje dramaturgię), dokumentalną (obejmuje wszelkiego rodzaju ikonografię), autoteliczną (uzupełnia tekst), kształcącą, poznawczą, informacyjną (bo wprowadza i utrwala wiedzę); wychowawczą, osobotwórczą, społeczną (bo kształtuje pożądany wzorzec zachowań); estetyczną (bo podnosi walory estetyczne, kształtuje upodobania); komunikacyjną (bo prowadzi dialog z odbiorcą); terapeutyczną, katarktyczną (bo wywołuje pozytywne uczucia),

${ }^{5}$ G. LeszCZyŃSKi, M. ZAJĄC, Książka i młody czytelnik: zbliżenia, oddalenia, dialogi. Studia i szkice, Warszawa: Wydawnictwo SBP 2013, s. 245-248.

${ }^{6}$ Ilustracje stanowią najczęściej reprodukcje dzieł lub subiektywną wizję ilustratora, która jest inspirowana oryginalnym dziełem i została świadomie zmieniona.

${ }^{7}$ Autorka powołuje się na następującą pozycję: K. GŁomBIowsKi, Książka w procesie komunikacji społecznej, Wrocław: Ossolineum 1980, s. 58; O ksiązce, pod red. J. Majerowej, Wrocław: Ossolineum 1987, s. 59.

${ }^{8}$ E. PIWOWARSKA, Ilustracja a ważne i trudne tematy w książkach dla dzieci, Warszawa: Ośrodek Wydawniczo-Poligraficzny SIM 2012, s. 48. 
kreacyjną (pobudza wyobraźnię) $)^{9}$. Wszystkie te funkcje są równie ważne w nauczaniu języków obcych, dlatego też korzystanie z książek o sztuce daje możliwość ich realizacji. Relacja dzieła sztuki i tekstu jest szczególnie ważna w procesie edukacyjnym, bowiem pokazuje uczniom intertekstualność kultury, a także motywację do poszukiwania ponadstandardowych połączeń między sztuką a literaturą, inspirując do działań interpretacyjnych wbrew schematom. Tego typu podejście nie wyklucza oczywiście myślenia o tekście czy też dziele sztuki w sposób fenomenologiczny, jednakże stanowi jedno z możliwych sposobów (propozycji) prowadzenia zajęć szkolnych i sprawdza się w określonych sytuacjach.

Współczesne książki na temat sztuki charakteryzuje przede wszystkim dostosowanie treści do młodego odbiorcy, dając mu zarówno wskazówki dotyczące interpretowania dzieła, jak i zachęcenie do tworzenia własnych interpretacji. Stosowane przez autorów zabiegi otwierają zupełnie inne możliwości patrzenia na dzieło. Łączą one specjalistyczną wiedzę o sztuce, elementy powieści biograficznej, reportaż, książkę ilustrowaną i powieść dla dzieci. W związku z tym można stwierdzić, że usytuowane są na pograniczu kilku gatunków, co umożliwia różnorodne sposoby pracy z tego typu utworami.

\section{REKOMENDACJE - PERSPEKTYWA GLOTTODYDAKTYKA}

Jak już wspomniano, rozwiązania zaprezentowane w niniejszej pracy są skiełv rowane do nauczycieli, którzy pracują z dziećmi i młodzieżą na zajęciach języka polskiego jako obcego zarówno w polskim systemie edukacji, jak i w szkołach za granicą czy na kursach językowych. W nauczaniu języków obcych obraz może pobudzać do rozmowy, kształtując sprawność mówienia - przy każdym z obrazów możemy poprosić uczniów o komentarz związany z klasycznym opisem obrazu oraz opisem własnych uczuć wynikających z obcowania z dziełem ${ }^{10}$. Obok tej podstawowej funkcji, jaką pełni obraz, na lekcji warto podkreślić, że może on stać się także przyczynkiem do tworzenia tekstu pisanego, połączenia analizy zagadnienia prezentowanego przez dzieło z fragmentem filmu, słuchowiska (kształcenie sprawności słuchania) lub z tekstem pisanym (kształcenie czytania).

\footnotetext{
${ }^{9}$ Funkcje zostały wskazane za E. Piwowarską, tamże, s. 50.

${ }^{10} \mathrm{~W}$ związku z koniecznym ograniczeniem mojej rozprawy pomijam pracę z dziełem sztuki na lekcji języka polskiego jako obcego, skupiając się na wykorzystaniu treści prezentowanych we współczesnych książkach o sztuce, czyli obrazu wraz z tekstem. Osoby zainteresowane pracą stricte z obrazem odsyłam do pozycji B. SzAŁASTY-RogowsKIEJ, ,,Tekst literacki i malarski w nauczaniu cudzoziemców”. Literatura bliska i daleka, Katowice: Wydawnictwo Uniwersytetu Śląskiego 2017. Autorka wskazuje ciekawe punkty pracy z tekstami literackimi oraz malarskimi.
} 
Sztuka dla małolatów. Inspirujące wprowadzenie do fascynującego świata sztuki pod red. Małgorzaty Denys jest pozycją, która z jednej strony inspiruje do własnych działań twórczych, z drugiej pozwala odkryć historię sztuki. Książka podzielona jest na 3 rozdziały: Sztuka wczesna, Sztuka współczesna, Rzeźba. W każdym z rozdziałów omówione są zagadnienia teoretyczne wraz z najbardziej znanymi reprezentantami danego nurtu i przykładami uznanych tekstów kultury. Krótkie komentarze do dzieł mogą stanowić jedynie punkt wyjścia do dalszej rozmowy - np. bardzo ciekawym i pobudzającym do działania podrozdziałem jest część Twarze w sztuce, gdzie pojawia się przekrojowe ujęcie tematu, ukazujące motyw na przestrzeni wieków, np.:

Lato 1573 r., Giuseppe Arcimboldo, olej na płótnie. Arcimboldo zyskał sławę dzięki swoim oryginalnym portretom ludzkich głów, które układał z owoców, kwiatów i warzyw występujących w danej porze roku, a następnie malował.

Jeśli tekst okaże się zbyt trudny językowo, jest on na tyle krótki, że lektor może go uprościć lub objaśnić poszczególne słowa. Lekcję z wykorzystaniem tych fragmentów książki można rozpocząć od dyskusji na temat twarzy - opis wyglądu, emocji (zobacz: aneks). Uczniowie mogą spróbować wyrazić różne uczucia. Jeśli dopiero poznają słownictwo, można rozdać karteczki z obrazkami poszczególnych emocji wraz z podpisem i po wprowadzeniu słownictwa zagrać np. w kalambury - jedna z osób pokazuje, inne odgadują. Jeśli słownictwo jest za trudne, na początku uczniowie mogą otrzymać wszystkie obrazki z podpisami na jednej karcie i zgadywać na tej podstawie, z czasem można zabrać rysunki, pozostawiając jedynie podpisy. Po tej części lekcji można wykorzystać fragmenty omawianej przeze mnie pozycji i pokazać różnorodne sposoby portretowania twarzy. W przypadku młodszych uczniów można rozpocząć pracę od układania portretów, podobnych do tych, które tworzył Arcimboldo - uczniowie dostają owoce lub warzywa (mogą być też wycięte obrazki) i układają z nich portrety. $\mathrm{W}$ ten sposób uczą się lub utrwalają słownictwo z zakresu żywienia. Praca z ukazanymi twarzami może zakończyć się np. wylosowaniem jednej z twarzy i opowiedzeniem o sobie - „kim jestem, jak się czuję, co myślę”. Inni uczniowie mogą zgadywać, którą postać pokazuje wybrany uczeń.

Ponadto materiał ten umożliwia także rozmowę na temat społecznej funkcji sztuki. W tym celu należy wybrać odpowiedni fragment, np.:

Nina Llorando (Płacząca dziewczynka), XX wiek, Oswaldo Guayasamin, olej na płótnie. Ekwadorski artysta namalował ponad sto obrazów, ukazujących ból i cierpienie rodowitych mieszkańców Andów. 
Tekst i umieszczona praca artysty może stać się przyczynkiem do rozmowy na temat globalnych problemów i ich przyczyn oraz możliwości przeciwdziałania, a także sposobów przedstawiania ludzkiego cierpienia w sztuce.

W książce wyjaśnione zostały techniki, które na przestrzeni wieków wykorzystywano do tworzenia dzieł: np. proces powstawania papirusu czy farb temperowych. Można te zadania traktować jako ćwiczenia typu: „zrób to sam”. Twarz to tylko jeden z wielu rozdziałów, które mogą pokazywać uczniom różnorodność sposobów przedstawiania określonej tematyki w sztuce.

Coissard Sylvain, Lemoine Alexis (Prawdziwa!) Historia sztuki to niezwykle ciekawe, choć bardzo skromne w treści tekstowe dzieło. Książka składa się z tryptyków, które pokazują „prawdziwą” historię poszczególnych obrazów. Autorzy zmieniają sposób myślenia o sztuce, wychodząc ze schematu. Przedstawiają dzieło w dwóch różnych ujęciach - przed i po „zdarzeniu”, które wpłynęło na ostateczny kształt dzieła. Na przykład bohater Krzyku Edvarda Muncha pierwotnie idzie uśmiechnięty w peruce, jednak wiatr porywa jego tupecik, więc postać zaczyna krzyczeć. Pokazanie uczniom tego typu rozwiązań może stanowić ciekawy punkt wyjścia do tworzenia własnych interpretacji sztuki poprzez tworzenie podobnych prac. Obraz dopasowujemy do tematyki zajęć, może służyć utrwaleniu leksyki z danego obszaru lub stanowić utrwalenie zasad gramatycznych (np.: stopniowanie przymiotników „,mój obraz jest bardziej kolorowy, oryginał jest smutniejszy").
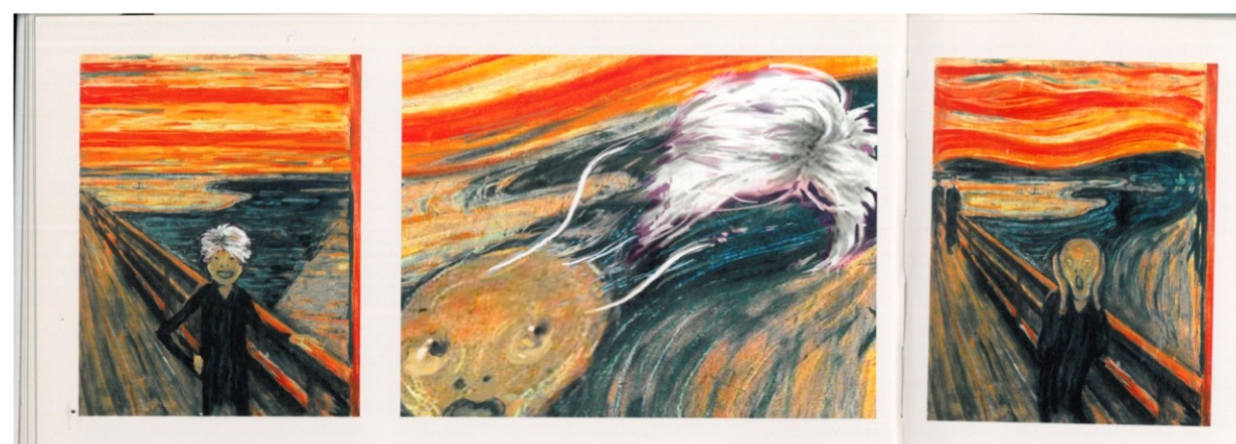

Coissard S., Lemoine A., (Prawdziwa!) Historia sztuki, Warszawa: Muchomor 2014

Kolejną z zaproponowanych pozycji jest dzieło traktujące o sztuce współczesnej. Sebastian Cichocki w utworze S.Z.T.U.K.A.* (*Szalenie Zajmujace Twory Utalentowanych i Krnąbrnych Artystów) przedstawia w niezwykle lekki i zabawny sposób siłę sztuki współczesnej, pokazując jej wyjątkowość i oryginalność. Książka przedstawia 51 dzieł współczesnych artystów z całego świata, wśród 
nich pojawiają się m.in.: Marcel Duchamp, Edward Krasiński, Gregor Schneider, Jeff Wall i wielu innych wybitnych twórców. Choć teksty Cichockiego są trudne dla uczniów uczących się języka polskiego (szczególnie na początkowych poziomach), można je z powodzeniem uprościć lub stworzyć krótkie streszczenie. Pomimo tego książka nie traci na wartości, ponieważ przede wszystkim inspiruje do prowadzenia ciekawych lekcji, oferując świeże spojrzenie na zagadnienia dotyczące sztuki. Można ją wykorzystać jako dopełnienie zajęć dodatkowymi treściami ze sztuki współczesnej, pokazując uczniom nowe oblicza tworzenia. Oto kilka sugestii, w jaki sposób z owych treści korzystać w praktyce:

Rozdział przedstawiający Katharinie Fritsch i jej dzieło pt. Szczurzy król, inspirowane jedną z niemieckich legend:

Czy słyszeliście kiedyś o szczurzym królu? Legenda ta jest bardzo popularna w Niemczech. Mówi się, że raz na kilkadziesiąt lat rodzi się stwór złożony z kilkunastu, a nawet kilkudziesięciu szczurów zrośniętych ogonami. Jak łatwo się domyślić, nie wzbudza on raczej niczyjej sympatii. Skoro wielu ludzi jest w stanie przerazić nawet zwykła polna mysz, to co dopiero takie szczurze monstrum! Ale król to król - niemieccy rolnicy wierzyli, że ma on władzę nad innymi gryzoniami, a jego pojawienie się jest znakiem zbliżającej wojny albo innego nieszczęścia.

Fragment ten można wykorzystać podczas lekcji dotyczącej kultur poszczególnych krajów, podczas której uczniowie mogliby opowiedzieć o legendach dotyczących bliskich im miejsc i porównać teksty.

Cichocki opowiada także o fotografiach wykonywanych przez Jeffa Walla, który wykonywał zdjęcia tego samego miejsca przez rok. Później ułożył je w jedtı ną spójną historię. Uczniowie także mogą fotografować przez ustalony okres jedno z wybranych miejsc kultury. Następnie ze zrobionych fotografii można wykonać kolaże, zarówno techniką standardową - wywołując i przyklejając zdjęcia, jak i w programie komputerowym (wówczas można wydrukować gotowe projekty). Pomysł ten to projekt kulturowy na temat ważnych zabytków danej miejscowości. Uczniowie mogą przygotować także opisy wybranych punktów, tworząc przewodnik.

Ciekawa wydaje się omówiona przez autora koncepcja sztuki według Rirkrita Tiravanijego, sam pomysł na tworzenie dzieła z ,żywych ludzi” i jej kontaktu z widzem tworzy możliwość dyskusji na temat spędzania wolnego czasu, kontaktów z drugim człowiekiem (przykładowe pytania: Jak to wygląda w twoim kraju? Jakie są zwyczaje spędzania wolnego czasu? Co myślisz o idei sztuki zaprezentowanej przez autorkę?). Poniżej fragment omawianej koncepcji. Został on skrócony, co pozwoliło na skupienie się na najważniejszych kwestiach: 
Rirkrit Tiravanija pochodzi z Tajlandii. Uważa, że większą sztuką jest spotkać się z ludźmi i spędzić z nimi dobrze czas, niż postawić w muzeum nieruchomą rzeźbę, której nikomu nie wolno dotknąć. Dlatego na wystawach Rirkrita rzadko jest coś do oglądania - zawsze jednak dzieje się coś interesującego! Najczęściej artysta gotuje dla publiczności wspaniałe tajskie jedzenie.

Każda z tych pozycji dostosowuje przekaz do możliwości językowych młodego odbiorcy. Przedstawione w artykule pozycje są jedynie subiektywnym wyborem pozycji, z których można korzystać podczas prowadzenia zajęć z języka polskiego jako obcego. Zainteresowanych poszerzeniem materiałów o inne, wartościowe książki oscylujące wokół tematów sztuki odsyłam do poniższej listy, w której podaję kolejne tytuły:

- Oskar Brenifer, Remi Corgeon, Piękno i sztuka, co to takiego?

- María Hesse, Frida Kahlo. Biografia

- Bird Michael, Gwiaździsta noc Vincenta i inne opowieści. Historia sztuki dla dzieci

- Ewa Jałochowska, Historia sztuki dla dzieci i rodziców Rozmowy z Kajtkiem

- Susie Hodge, Claire Goble, Dlaczego sztuka petna jest golasów?

\section{PODSUMOWANIE}

Skierowane do młodszych czytelników książki poruszające temat sztuki mogą stanowić bardzo ciekawe dopełnienie lekcji języka polskiego jako obcego lub zbudować lekcję wokół zagadnień przedstawionych w wybranym fragmencie utworu. Utwory te stanowią swojego rodzaju hybrydę gatunkową, łącząc ze sobą język popularnonaukowy z charakterystycznymi dla książek obrazkowych ilustracjami i odautorskimi komentarzami, które służą nie tylko wyjaśnianiu (językiem dziecka) sztuki i jej historii, ale także inspirują do osobistych refleksji, wynikających z bliskiego kontaktu z dziełem. Mogą być one przyczynkiem do własnej twórczości uczniów, zarówno artystycznej, jak i literackiej, oraz prowadzenia dyskusji polegającej na wymianie doświadczeń wynikającej z kontaktu z dziełem. Zaproponowane utwory są, ze względu na ograniczenie rozprawy, jedynie subiektywnym wyborem kilku, moim zdaniem, wartych uwagi pozycji. Jednakże współczesny rynek książki oferuje naprawdę wiele książek o tematyce artystycznej, którymi niewątpliwie warto urozmaicać lekcje języka polskiego jako obcego. 
ANEKS

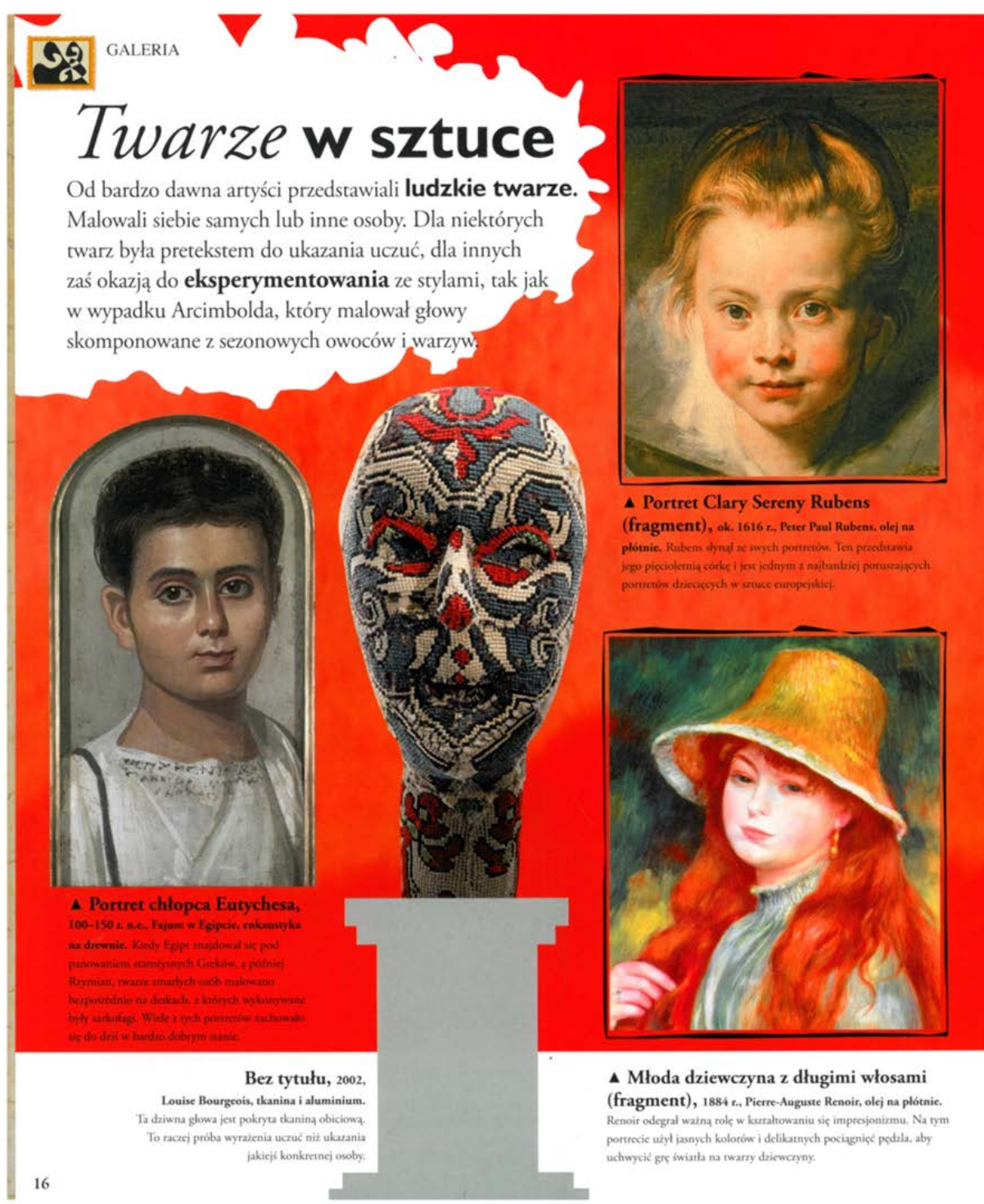

Sztuka dla matolatów. Inspirujące wprowadzenie do fascynującego świata sztuki, ed. M. Denys, Warszawa: Wydawnictwo G+J RBA 2010 


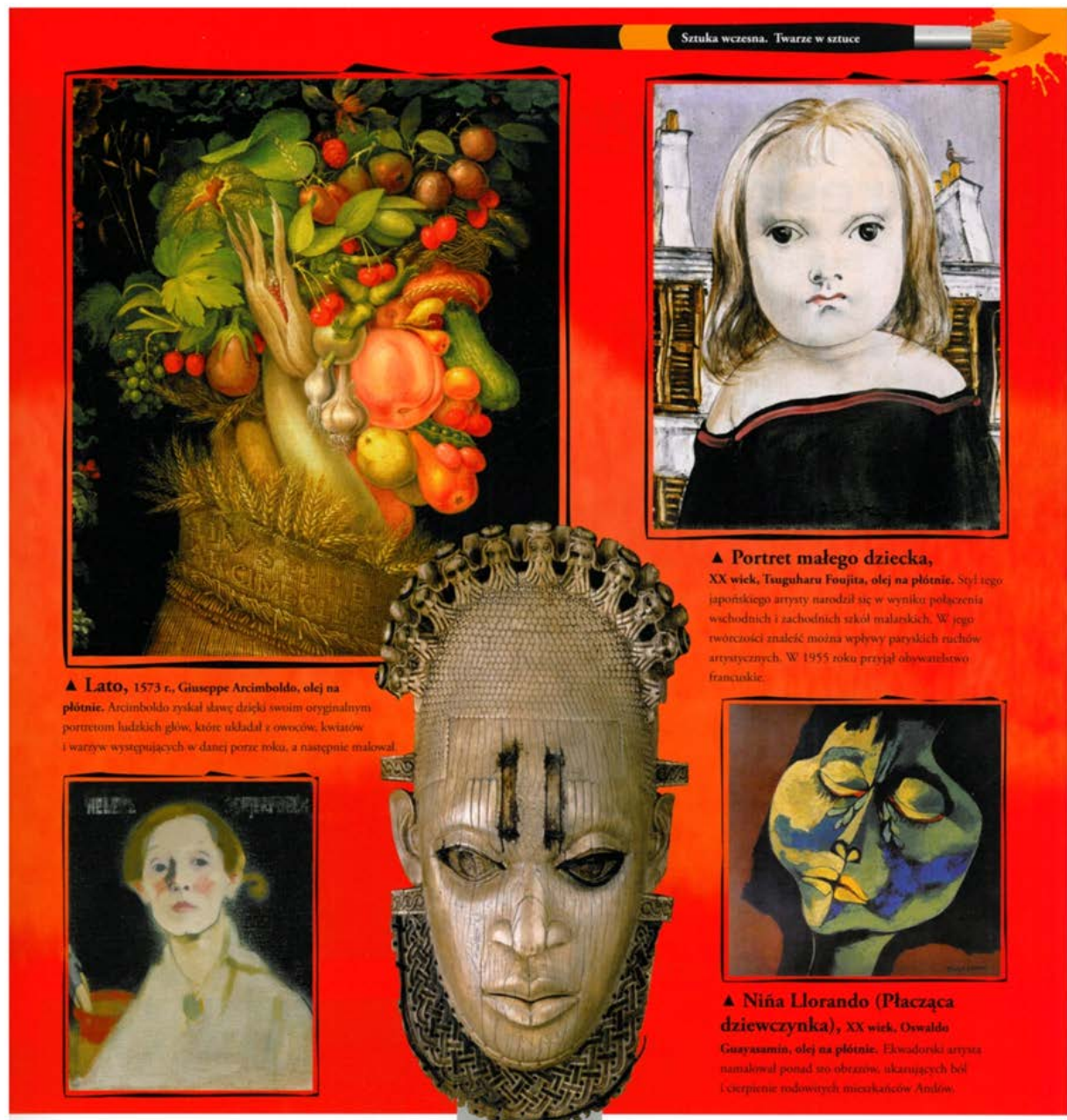

A Autoportret z czarnym tłem, 1915 r., Helene Schjerfbeck, olej na plótnie. Finiska malarka Helene Schjerfbech

\ Maska, ok. 1600 r., Benin, Nigeria, koíc

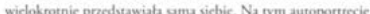
53 lata. Pod konic tycia ukarywaha sicbic jako kruchy i staba kobick u progu smierci.

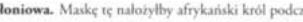

specialnej ceremennii upamiçrniajacej jcgo matks.

Zorcah wyrrestbiona z koici stoniowej i prevpomina rwark prawdaiwej kobicty.

Sztuka dla małolatów. Inspirujące wprowadzenie do fascynujacego świata sztuki, ed. M. Denys, Warszawa: Wydawnictwo G+J RBA 2010 


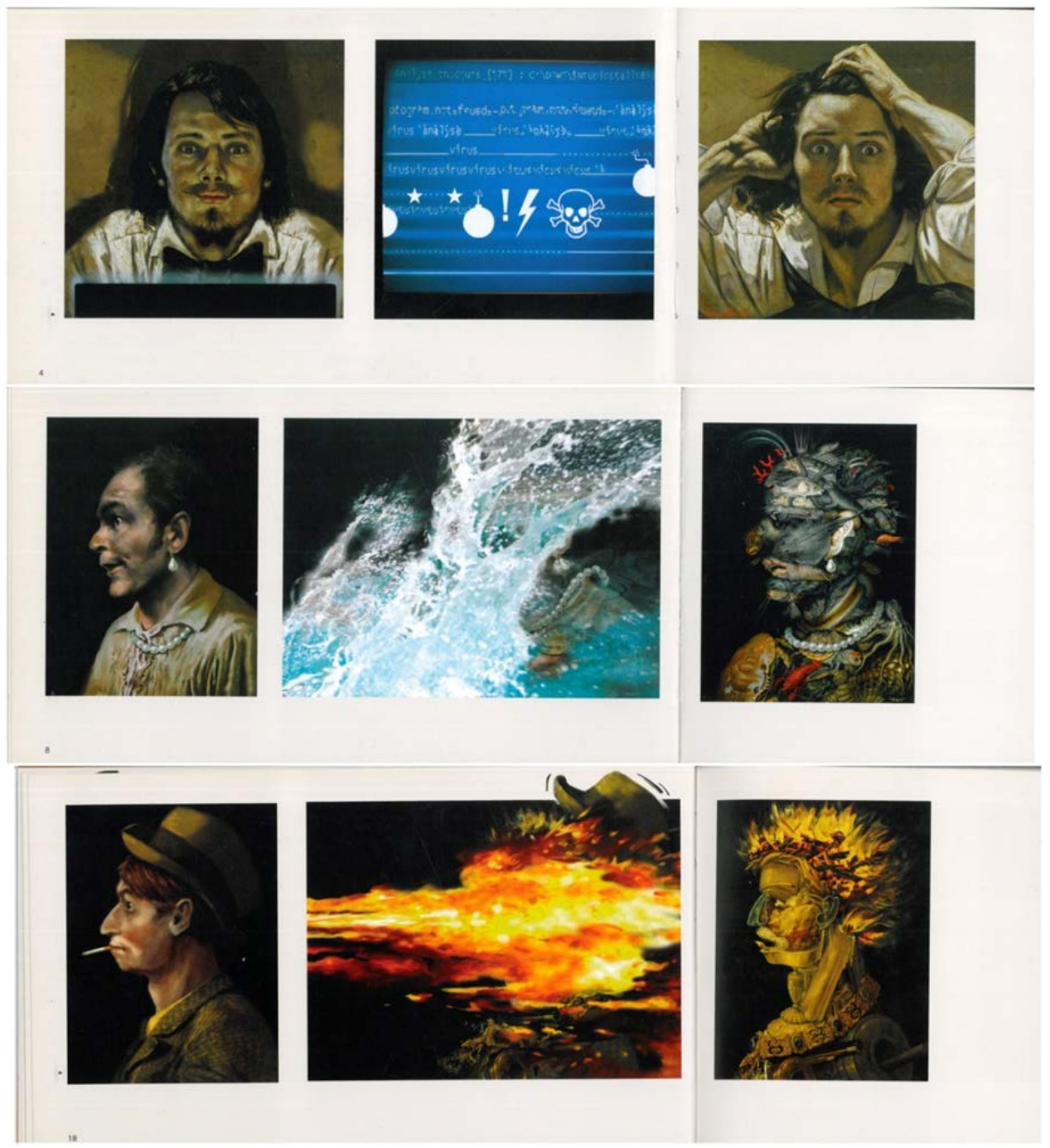

S. Coissard, A. Lemoine, (Prawdziwa!) Historia sztuki, Warszawa: Muchomor 2014 


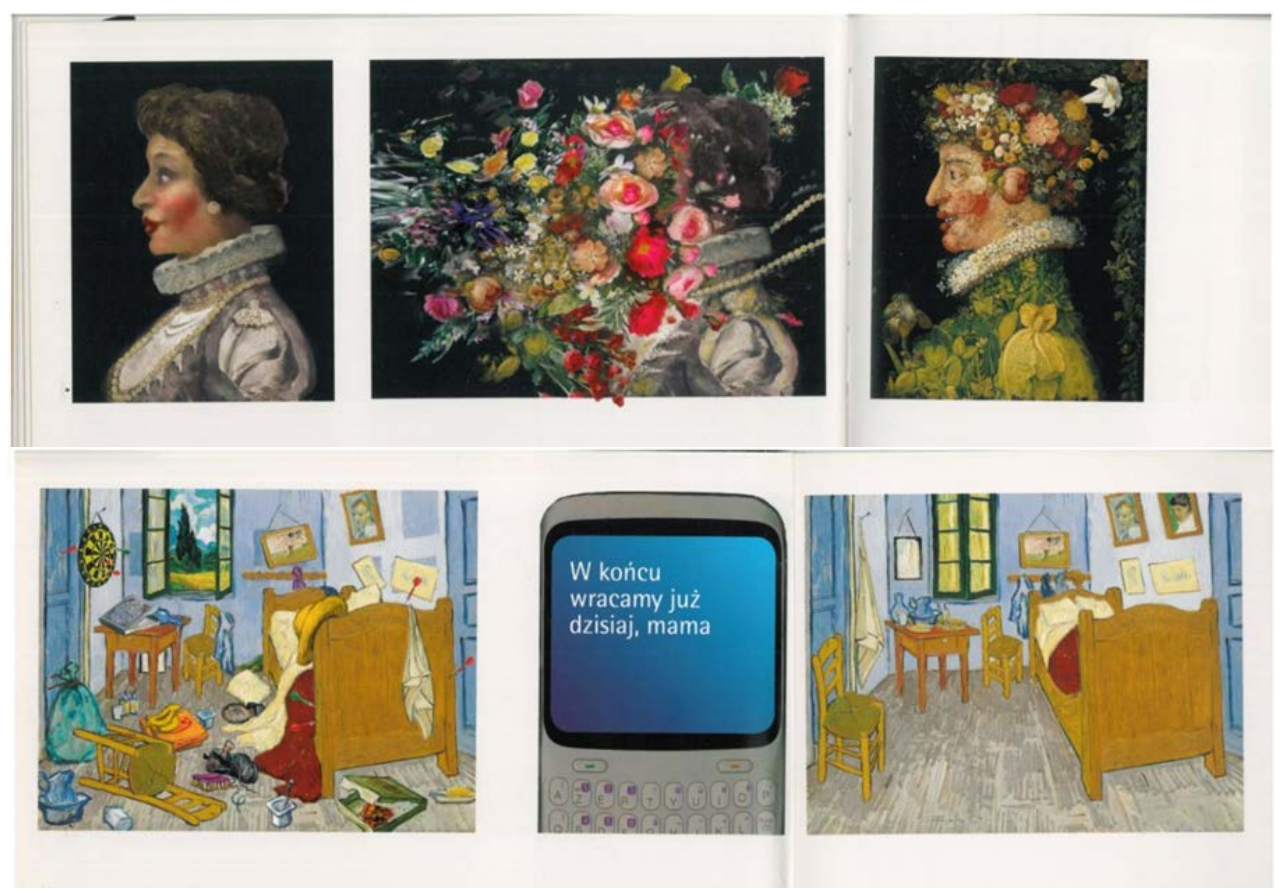

S. Coissard, A. Lemoine, (Prawdziwa!) Historia sztuki, Warszawa: Muchomor 2014

\section{BIBLIOGRAFIA}

Bird M., Gwiaździsta noc Vincenta i inne opowieści. Historia sztuki dla dzieci, Warszawa: Nasza Księgarnia 2017.

Brenifer O., Corgeon R., Piękno i sztuka, co to takiego?, Poznań: Wydawnictwo Zakamarki 2016.

Cісноскі S., S.Z.T.U.K.A.* (*Szalenie Zajmujące Twory Utalentowanych i Krnąbrnych Artystów), Warszawa: Wydawnictwo Dwie Siostry 2011.

Coissard S., Lemoine A., (Prawdziwa!) Historia sztuki, Warszawa: Muchomor 2014.

Sztuka dla małolatów. Inspirujace wprowadzenie do fascynującego świata sztuki, ed. M. DENYS, Warszawa: Wydawnictwo G+J RBA 2010.

Hesse M., Frida Kahlo. Biografia, Katowice: Wydawnictwo Sonia Draga 2018.

Hodge S., Goble C., Dlaczego sztuka petna jest golasów?, Warszawa: Wydawnictwo Naukowe PWN 2017.

JaŁochowsKa E., Historia sztuki dla dzieci i rodziców Rozmowy z Kajtkiem, Wrocław: Wydawnictwo Bukowy Las, cop. 2012.

KRUSZYŃSKa E., „O kryzysie czytania i książce ikono lingwistycznej”. Dziecko i literatura we współczesnym świecie, pod red. B. Moraczewskiej, E. Oberlana, Włocławek: Państwowa Wyższa Szkoła Zawodowa 2012. 
Leszczyński G., Zając M., Książka i młody czytelnik: zbliżenia, oddalenia, dialogi. Studia i szkice, Warszawa: Wydawnictwo SBP 2013.

LiPIŃSKa E., „Przekład intersemiotyczny w glottodydaktyce polonistycznej”. Tłumaczenie dydaktyczne w nowoczesnym kształceniu językowym, pod red. E. Lipińskiej, A. Seretny, Kraków: Księgarnia Akademicka 2016.

Piwowarska E., Ilustracja a ważne i trudne tematy w ksiązkach dla dzieci, Warszawa: Ośrodek Wydawniczo-Poligraficzny SIM 2012.

SzaŁASta-Rogowska B., ,,Tekst literacki i malarski w nauczaniu cudzoziemców”. Literatura bliska i daleka, Katowice: Wydawnictwo Uniwersytetu Śląskiego 2017.

\section{WSPÓŁCZESNE KSIĄŻKI O SZTUCE JAKO NARZĘDZIE DYDAKTYCZNE NA ZAJĘCIACH JĘZYKA POLSKIEGO JAKO OBCEGO}

\section{Streszczenie}

Sztuka tworzy przestrzeń do rozmowy na temat emocji, towarzyszących im barw, faktur, przedstawionych przez autora ujęć, sytuacji, bohaterów. Obserwowanie dzieła winno być czynnym aktem twórczej rozmowy z własnym doświadczeniem i wrażliwością. Współczesny rynek książki dla dzieci i młodzieży proponuje bogatą ofertę utworów o tematyce artystycznej. Mają one przedstawić młodszym odbiorcom sztukę i jej historię w przystępny i ciekawy sposób. Pokazują obraz nowoczesnego myślenia o edukacji artystycznej, skupionej na odbiorze sztuki z perspektywy młodego uczestnika kultury i jego kompetencji. Celem artykułu jest omówienie współczesnej oferty wydawniczej wraz ze wskazaniem praktycznych możliwości wykorzystania omówionego materiału podczas nauki języka polskiego jako obcego. Wskazane przykłady dzieł obejmują zarówno polski, jak i zagraniczny rynek wydawniczy.

Słowa kluczowe: glottodydaktyka; sztuka; literatura dziecięca; dydaktyka; książki obrazkowe.

\section{USING CONTEMPORARY BOOKS ABOUT ART AS A DIDACTIC TOOL ON LESSONS OF POLISH AS FOREIGN LANGUAGE}

\section{Summary}

Art creates a space for conversation about emotions, colors, textures, situation and characters presented by the author. Observing the work should be an active act of creative conversation with ourselves experience and sensitivity. The piece of art could be an inspiration for the communicative situation so it might be used while learning foreign languages. Contemporary book market for children and youth offers a wide range of books about art and artistic activities. It presents art and its history in an accessible and interesting way especially for younger audiences. The use of the latest books about art shows a picture of modern thinking about artistic education. It focuses on the reception of art from the perspective of a young participant of culture and their abilities. The aim of that article is to introduce the modern publishing offer and indicate the practical possibilities of using book about art while learning Polish as a foreign language. These examples of works include both - the Polish and foreign publishing market.

Key words: Polish as a Foreign Language; art; children's literature; didactics; picture books. 